\title{
Climate change scenarios and its impact on water resources of Langtang Khola Basin, Nepal
}

\author{
TIRTHA RAJ ADHIKARI ${ }^{1}$, LOCHAN PRASAD DEVKOTA ${ }^{1}$ \\ \& ARUN BHAKTA SHRESTHA ${ }^{2}$ \\ 1 Central Department of Hydrology and Meteorology, Tribhuvan University, Kathmandu, Nepal \\ tirtha43@yahoo.com \\ 2 International Centre for Integrated Mountain Development, Kathmandu, Nepal
}

\begin{abstract}
General Circulation Models (GCMs) successfully simulate future climate variability and climate change on a global scale; however, poor spatial resolution constrains their application for impact studies at a regional or a local level. The dynamically downscaled precipitation and temperature data were used for the future climate scenarios prediction for the period 2000-2050s, under the Special Report on Emissions Scenarios (SRES) A2 and A1B scenarios. In addition, rating equation was developed from measured discharge and gauge (stage) height data. The generated precipitation and temperature data from downscale and rating equation was used to run the HBV-Light 3.0 conceptual rainfall-runoff model for the calibration and validation of the model, gauge height was taken in the reference period (1988-2009). In the HBV-Light 3.0, a GAP optimization approach was used to calibrate the observed streamflow. From the precipitation scenarios with SRES A2 and A1B emissions at Kyanging, an increase of precipitation during summer and spring and a decrease during winter and autumn seasons was shown. The model projected annual precipitation for the $2050 \mathrm{~s}$ of both the A2 and A1B scenarios are $716.4 \mathrm{~mm}$ and $703.6 \mathrm{~mm}$, respectively. Such precipitation projections indicate the future increase of precipitation in all seasons except the summer. By the end of the $2050 \mathrm{~s}$ simulation projects an increase maximum (minimum) discharge of $37.8 \mathrm{~m}^{3} / \mathrm{s}(13.9$ $\left.\mathrm{m}^{3} / \mathrm{s}\right)$ for A1B scenario and $36.2 \mathrm{~m}^{3} / \mathrm{s}\left(14.3 \mathrm{~m}^{3} / \mathrm{s}\right)$ for A2 scenario. A maximum projected discharge will increase for all seasons except for spring, whereas the minimum will decrease in summer.
\end{abstract}

Key words water resources; Nepal; climate change

\section{INTRODUCTION}

Climate and water studies play an important role in the protection of the environment. This study attempts to assess the downscaling of GCMs simulated gridded data to high resolution regional gridded or point data models: dynamical climate model, weather typing, transform function and scenario generation (http://www.cics.uvic.ca/scenarios/index.cgi?Scenarios). The Coupled Global Climate Model (CGCM3) of National Centres for Environmental Prediction (NCEP) predictors have been considered as the independent variables for multiple regression analysis for climate observation as a dependent variable. Finally, mean sea level pressure, surface vorticity, surface divergency, $500 \mathrm{hPa}$ geo-potential heights and specific humidity at $500 \mathrm{hPa}$ for temperature downscaling, and meridional velocity, surface zonal velocity and 850 hpa geopotential height for precipitation downscaling were selected as significant predictors. Finally, optimization of the model was completed by applying the ordinary least squares method. In the above analyses, observed and NCEP data sets have a year length of 365 days (366 in leap years). The historical meteorological daily observed climate data are used as a predictor and input in the statistical downscaling method.

\section{STUDY AREA}

The Langtang River catchment $\left(583.41 \mathrm{~km}^{2}\right)$ is located approximately $100 \mathrm{~km}$ north of Kathmandu, Nepal. In this study, data from Syaprubesi hydrological station at latitude $28009^{\prime} 30^{\prime \prime}$ and longitude $85020^{\prime} 45^{\prime \prime}$, and Langtang Kyanging meteorological station at latitude $28012^{\prime} 00^{\prime \prime}$ and longitude $85034^{\prime} 00^{\prime \prime}$ are used. The elevation of the study area ranges from Syapru besi, 434 m.a.s.l. up to the peak of Langtang Lirung at 7234 m.a.s.l., with an average altitude of 4334 m.a.s.l. In total, $26 \%\left(153.14 \mathrm{~km}^{2}\right)$ of the catchment is glacierized. The glacier tongues below 5200 m.a.s.l. is $32 \mathrm{~km}^{2}$ long and are generally debris covered (Immerzeel et al. 2011). The main valley is divided by the Langtang Khola River and it is typically U-shaped. The Gandaki River system in central Nepal consists of the Kaligandaki Mustang and converges with the Trishuli at Deoghat in 
Chitwan, the river is then called the Narayani Langtang Khola and is one of the snow- and glacierfed rivers and is the main tributary of Narayani basin (Trishuli). The extreme daily simulated mean discharge at Syaprubasi hydrological station is $60.5 \mathrm{~m}^{3} / \mathrm{s}$.

\section{METHODOLOGY}

The daily climate data were collected from the Department of Hydrology and Meteorology (DHM), Government of Nepal. Meteorological data used in this study include daily precipitation, daily maximum temperature and daily minimum temperature of Kyanging Langtang snow and glacier hydrology station temperature. The products of scenarios generated by using CGCM3 temperature and precipitation data were used with the HBV (Hydrologiska Byråns Vattenbalansavdelning) light 3.0 hydrological model for the calculation of future discharge from Langtang Khola catchment at Syaprubesi. Seibert (2005) describes the model as follows: daily discharge is simulated by HBV light 3.0 using daily rainfall, temperature and potential evaporation as input. In this study, seasons in Nepal are classified as: winter (DJF) December of the previous year to February; spring (MAM) March to May; summer (JJAS) June to September; and autumn $(\mathrm{ON})$ October to November. Four applications of computer software programs are applied in this study: (1) SDSM for generating daily climate temperature and precipitation scenarios (SDSM 4.2), developed by Wilby and Dawson (2007) in the UK, is chosen for developing daily climate scenario study, (2) hqrating model (developed by the Department of Hydrology and Meteorology, Government of Nepal) to develop the rating curve, (3) ArcGIS 9.3 for glacier area delineation, and (4) HBV Light 3.0 for discharge modelling (Seibert 2005).

Continuous discharge measurement of a stream is very difficult and costly, but the continuous record of river stage can be easily obtained. Hence to compute the daily flow, there should be an adequate correlation between stage and discharge. Discharge ratings for gauging stations are usually determined empirically using periodic measurements of discharge and stage (Reddy 2005). The discharge measurements are made by current meter. Measured discharges are then plotted against concurrent stages on graph paper to define the rating curve. Hydrological data used in this study are: daily gauge (stage) height (1994-2010) and occasional discharge measurement data of Syaprubesi hydrological station (1979-2009). These unpublished discharge measurement data are available from the Department of Hydrology and Meteorology (DHM). On the basis of this discharge measurement and stage height data the rating equation (1) was developed in Syaprubesi hydrological station of Langtang Khola:

$$
Q=0.328 *(\mathrm{H}+2.022)^{3.378}
$$

\section{Langtang Khola Basin}

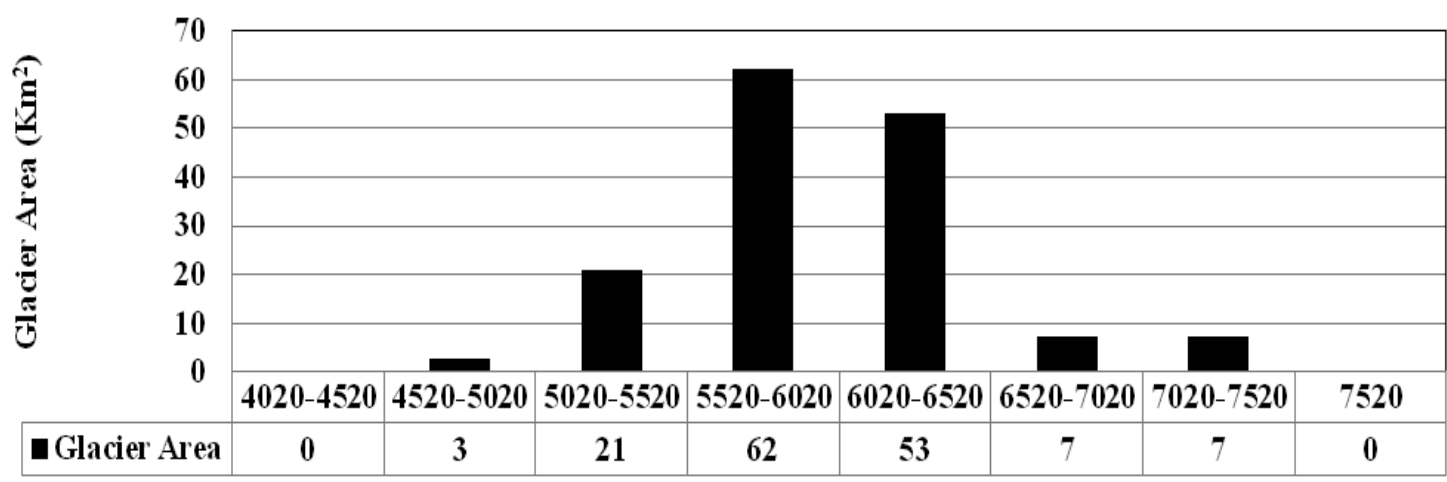

Fig. 2 Glacier Area in elevation wise.

In this study the watershed is divided into 13 elevation and one vegetation zone by using ArcGIS 9.3 for glacier area delineation. The delineated area histogram of Langtang Khola basin glacier area is shown in Fig. 2. The largest glacier area, $62 \mathrm{~km}^{2}$, occurs in the $5520 \mathrm{~m}$ elevation 
zone and the lowest glacier area, $3 \mathrm{~km}^{2}$, is found in the elevation of $4520 \mathrm{~m}$. HBV light 3.0 is applied on the time period from January 2002 to December 2004, with the discharge data recorded in Syaprubasi station. Firstly automatic Generatic Algorithm Package (GPA) optimization was applied and then manual calibration was done to refine the parameters by "trial and error". In addition to visual inspection of the simulated time series and the observed, several objective criteria were used to assess the best parameter set. Validation was done with the parameter sets from the GPA optimization for comparison. The model was validated for the Langtang Khola Syaprubasi from 2005 to 2009, with the same parameter sets of calibration. At Kyanging, observed daily temperature data are available from 1988 to 2009. Consequently, observed temperature and NCEP data from 1988 to 1995 were used for downscale calibration and data from 1996 to 2003 were used for its validation.

\section{Modelling calibration and validation}

The seasonal and annual values of observed (OBS) and NCEP simulated temperature, including their percentage difference, are presented in Table 1: depicting the highest seasonal percentage of difference in maximum and minimum temperatures were $-0.1^{\circ} \mathrm{C}$ and $-1.0^{\circ} \mathrm{C}$, respectively, in the calibration. Similarly, the annual percentage of different maximum temperature is $1.3^{\circ} \mathrm{C}$ and minimum temperature is $1.0^{\circ} \mathrm{C}$ in the validation. These percentage of difference indicate a degree of reliability of the SDSM temperature calibration and validation process at Langtang Kyanging shown in Table 2. Observed daily precipitation data were available from 1988 onwards. Hence, observed precipitation and NCEP predictor data from 1988 to 1995 were utilized for GCMS calibration and data from 1996 to 2003 were used for its validation. Seasonal and annual values of observed and NCEP simulated total precipitation and their difference are presented in Table 1. The precipitation for NCEP calibrated (NCEP_Cal) scenarios of spring, summer and autumn are increased whereas it is decreased in winter, showing summer percentage of difference $-15 \%$ (of observed summer total). But in the NCEP validation (NCEP_Val) process Table 2, showing the summer percentage of difference $12.7 \%$ (of observed summer total). This explains relatively poor reliability of the SDSM precipitation calibration process, which could be due to altitudinal effect of the summer monsoon at Langtang Kyanging.

Table 1 Calibration of observed data with CGCM3 of NCEP data.

\begin{tabular}{|c|c|c|c|c|c|c|c|c|c|c|c|c|}
\hline \multirow[b]{2}{*}{ Season } & \multicolumn{3}{|c|}{ Maximum Temp $\left({ }^{\circ} \mathrm{C}\right)$} & \multicolumn{3}{|c|}{ Minimum Temp $\left({ }^{\circ} \mathrm{C}\right)$} & \multicolumn{3}{|c|}{ Precipitation $(\mathrm{mm})$} & \multicolumn{3}{|c|}{ Discharge $\left(\mathrm{m}^{3} / \mathrm{s}\right)$} \\
\hline & OBS & $\begin{array}{l}\text { NECP } \\
\text { Cal }\end{array}$ & $\begin{array}{l}\% \text { of } \\
\text { diff }\end{array}$ & OBS & $\begin{array}{l}\text { NECP } \\
\text { Cal }\end{array}$ & $\begin{array}{l}\% \text { of } \\
\text { diff }\end{array}$ & OBS & $\begin{array}{l}\text { NECP } \\
\text { Cal }\end{array}$ & $\begin{array}{l}\% \text { of } \\
\text { diff }\end{array}$ & OBS & $\begin{array}{l}\text { NECP } \\
\text { Cal }\end{array}$ & $\begin{array}{l}\% \text { of } \\
\text { diff }\end{array}$ \\
\hline DJF & 2.1 & 2.4 & -0.3 & -7.7 & -6.7 & -1.0 & 12.8 & 10.9 & 14.7 & 17.5 & 15.5 & 11.8 \\
\hline MAM & 6.6 & 6.8 & -0.3 & -2.4 & -1.5 & -0.9 & 29.9 & 31.2 & -4.4 & 19.6 & 15.4 & 21.2 \\
\hline JJAS & 10.5 & 10.5 & 0.0 & 5.3 & 6.3 & -1.0 & 101.3 & 116.6 & -15.0 & 58.4 & 45.9 & 21.4 \\
\hline $\mathrm{ON}$ & 6.5 & 6.2 & 4.6 & -2.6 & -1.6 & 38.5 & 1.3 & 13.6 & -946.2 & 27.4 & 23.5 & 14.3 \\
\hline Annual & 6.8 & 6.9 & -0.1 & -1.2 & -0.2 & -1.0 & 535.0 & 618.4 & -15.6 & 33.4 & 26.9 & 19.5 \\
\hline
\end{tabular}

Table 2 Validation of observed data with CGCM3 of NCEP data.

\begin{tabular}{lllllllllllll}
\hline \multirow{3}{*}{ Season } & \multicolumn{3}{c}{$\begin{array}{l}\text { Maximum Temp }\left({ }^{\circ} \mathrm{C}\right) \\
\text { OBS }\end{array}$} & $\begin{array}{l}\text { NECP } \\
\text { Val of } \\
\text { diff }\end{array}$ & $\begin{array}{l}\text { Minimum Temp }\left({ }^{\circ} \mathrm{C}\right) \\
\text { OBS }\end{array}$ & $\begin{array}{l}\text { NECP } \\
\text { Val of } \\
\text { diff }\end{array}$ & $\begin{array}{l}\text { Precipitation }(\mathrm{mm}) \\
\text { OBS }\end{array}$ & $\begin{array}{l}\text { NECP } \\
\text { Val of }\end{array}$ & $\begin{array}{l}\text { Discharge }\left(\mathrm{m}^{3} / \mathrm{s}\right) \\
\text { diff }\end{array}$ & $\begin{array}{l}\text { OBS } \\
\text { NECP } \\
\text { Val of }\end{array}$ & $\begin{array}{l}\text { of } \\
\text { diff }\end{array}$ \\
\hline DJF & 3.7 & 2.5 & 1.2 & -5.3 & -6.6 & 1.3 & 8.1 & 11.1 & -36.7 & 16.5 & 9.1 & 44.7 \\
MAM & 7.7 & 7.0 & 0.8 & -0.1 & -0.9 & 0.8 & 32.1 & 31.6 & 1.4 & 17.8 & 7.2 & 59.2 \\
JJAS & 12.0 & 10.5 & 1.5 & 7.4 & 6.4 & 1.0 & 130.3 & 113.8 & 12.7 & 49.3 & 42.0 & 14.8 \\
ON & 8.5 & 6.7 & 21.2 & 0.5 & -0.5 & 200.0 & 15.6 & 12.5 & 19.9 & 23.8 & 20.9 & 12.2 \\
Annual & 8.3 & 7.0 & 1.3 & 1.2 & 0.2 & 1.0 & 673.0 & 608.5 & 9.6 & 28.9 & 21.8 & 24.6 \\
\hline
\end{tabular}




\section{Discussion for future climate and discharge scenarios}

GCMS-simulated seasonal and annual range of mean of 20 ensembles for temperature scenarios with $\mathrm{A} 2$ and $\mathrm{A} 1 \mathrm{~B}$ emission scenarios at Langtang Kyanging are shown in Table 3. In the maximum temperature of the model simulation feature the autumn temperature is warmer than winter, spring and summer. The Table shows that the model projects warmer days in every season of the entire 2050s for both emissions. The warming is higher in maximum than in minimum temperatures, indicating an increasing trend of future daily temperature range.

Similarly, GCMS-simulated seasonal and annual mean of temperature scenarios with SRES $\mathrm{A} 2$ and A1B emission scenarios at Langtang Kyanging are shown in Table 3. According to the Table, the model projects warmer days increased in every season up to the 2050s for both A2 and A1B scenarios. GCMS-simulated seasonal and annual mean for precipitation scenarios with SRES $\mathrm{A} 2$ and A1B emissions at Kyanging are shown in Table 3. Where, for both low and high emissions, the model generally projects an increase of precipitation during summer and spring, there is a decrease during winter and autumn seasons. Such precipitation projections indicate that there is sufficient to balance the deficit, indicating drier Langtang Kyanging due to the effects of enhanced greenhouse gas in the 2050s.

Table 3 Temperature and Precipitation both A1B and A2 Scenario.

\begin{tabular}{|c|c|c|c|c|c|c|c|c|c|c|c|c|c|c|c|c|}
\hline \multirow{3}{*}{ Season } & \multirow{2}{*}{\multicolumn{2}{|c|}{$\begin{array}{l}\text { Tmax* } \\
\text { A1B } \\
\text { Scenario }\end{array}$}} & \multirow{2}{*}{\multicolumn{2}{|c|}{ A2 Scenario }} & \multirow{2}{*}{\multicolumn{2}{|c|}{$\begin{array}{l}\text { Tmin** } \\
\text { A1B } \\
\text { Scenario }\end{array}$}} & \multirow{2}{*}{\multicolumn{2}{|c|}{ A2 Scenario }} & \multirow{2}{*}{\multicolumn{2}{|c|}{$\begin{array}{l}\text { Tmean*** } \\
\text { A1B } \\
\text { Scenario }\end{array}$}} & & & \multicolumn{4}{|c|}{ Precipitation $(\mathrm{mm}) * * * *$} \\
\hline & & & & & & & & & & & \multicolumn{2}{|c|}{ A2 Scenario } & \multirow{2}{*}{$\begin{array}{l}\text { A1B } \\
2020\end{array}$} & \multirow{2}{*}{$\begin{array}{c}\text { Scenario } \\
2050\end{array}$} & \multicolumn{2}{|c|}{ A2 Scenario } \\
\hline & 2020 & 2050 & 2020 & 2050 & 2020 & 2050 & 2020 & 2050 & 2020 & 2050 & 2020 & 2050 & & & 2020 & 2050 \\
\hline DJF & 1.0 & 1.5 & 1.1 & 1.3 & -6.8 & -6.0 & -6.9 & -6.1 & -3.1 & -2.3 & -3.0 & -2.5 & 10.8 & 10.1 & 7.4 & 6.9 \\
\hline MAM & 7.1 & 7.1 & 7.3 & 7.1 & -1.2 & -0.4 & -0.9 & -0.1 & 3.3 & 4.0 & 3.7 & 4.4 & 28.6 & 31.9 & 28.7 & 31.3 \\
\hline JJAS & 10.5 & 10.9 & 10.6 & 10.8 & 6.5 & 6.9 & 6.6 & 6.9 & 9.5 & 9.9 & 9.6 & 9.9 & 142.5 & 142.1 & 142.6 & 142.2 \\
\hline $\mathrm{ON}$ & 7.6 & 7.9 & 7.6 & 8.0 & 1.2 & 1.8 & 1.2 & 2.1 & 4.2 & 4.8 & 4.3 & 5.0 & 11.9 & 11.0 & 9.6 & 10.0 \\
\hline
\end{tabular}

*Maximum temperature $\left({ }^{\circ} \mathrm{C}\right),{ }^{* *}$ Minimum temperature $\left({ }^{\circ} \mathrm{C}\right), * * *$ Mean temperature $\left({ }^{\circ} \mathrm{C}\right)$ and $* * * *$ Precipitation $($ mm).

Table 4 Maximum and minimum discharge scenario.

\begin{tabular}{lllllllll}
\hline \multirow{3}{*}{ Season } & \multicolumn{3}{l}{ Maximum Discharge $\left(\mathrm{m}^{3} / \mathrm{s}\right)$} & \multicolumn{4}{c}{ Minimum Discharge $\left(\mathrm{m}^{3} / \mathrm{s}\right)$} \\
& \multicolumn{2}{l}{ A1B Scenario } & \multicolumn{2}{l}{ A2 Scenario } & \multicolumn{2}{c}{ A1B Scenario } & \multicolumn{2}{c}{ A2 Scenario } \\
& $2020 \mathrm{~S}$ & $2050 \mathrm{~S}$ & $2020 \mathrm{~S}$ & 2050S & $2020 \mathrm{~S}$ & $2050 \mathrm{~S}$ & $202 \mathrm{~S}$ & $2050 \mathrm{~S}$ \\
\hline DJF & 20.2 & 21.9 & 16.8 & 18.8 & 7.7 & 8.6 & 7.9 & 8.6 \\
MAM & 35.5 & 34.2 & 21.0 & 21.2 & 3.7 & 4.1 & 3.9 & 4.3 \\
JJAS & 55.9 & 56.4 & 58.5 & 57.0 & 24.9 & 23.1 & 25.6 & 24.7 \\
ON & 27.4 & 29.0 & 39.9 & 43.3 & 16.3 & 16.9 & 16.5 & 16.9 \\
Annual & 37.3 & 37.8 & 35.7 & 36.2 & 13.9 & 13.7 & 14.3 & 14.3 \\
\hline
\end{tabular}

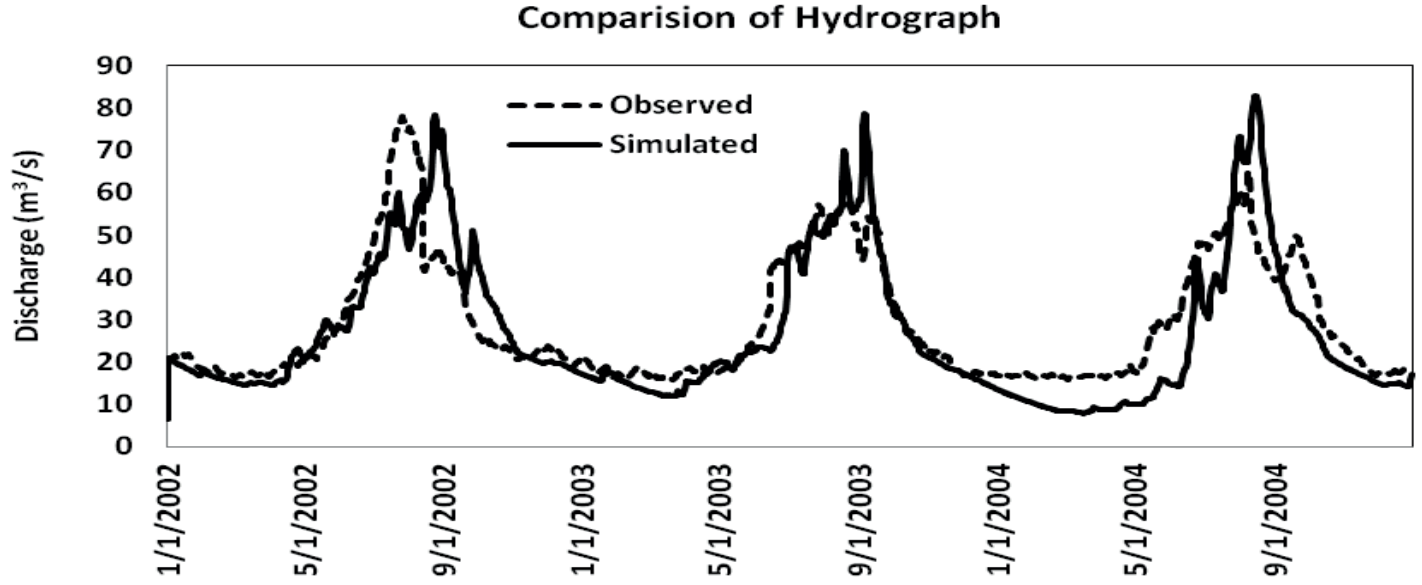

Fig. 2 Discharge calibrated hydrograph of Langtang Khola. 
The model is able to accurately simulate the daily discharge data at Syaprubasi hydrological station at the outlet of Langtang Khola (2002-2004). The observed and simulated hydrograph during the calibration period is shown in Fig 2. Downscale simulated results from temperature and precipitation in a daily scenario data were applied in HBV light 3.0 for a hydrological model. The seasonal and annual range of mean of the 2020s and 2050s ensembles for discharge scenarios with A2 and A1B at Syaprubasi hydrological station are shown in Table 4. The table shows that the model A1B projects maximum discharge increased in every season, except in the spring seasons of the entire 2050s century for the emission. By the end of the 2020s, simulation projects an increase of discharge in winter, summer and autumn, but a decrease in spring by the maximum (minimum) discharge of $37.3 \mathrm{~m}^{3} / \mathrm{s}\left(13.9 \mathrm{~m}^{3} / \mathrm{s}\right)$. Similarly, by the end of the $2050 \mathrm{~s}$ winter, spring and autumn will increase but in summer there will be a decrease of maximum (minimum) discharge of 37.8 $\mathrm{m}^{3} / \mathrm{s}\left(13.7 \mathrm{~m}^{3} / \mathrm{s}\right)$ for A1B scenario. Likewise, the 2020s and 2050s will both have an increase of discharge in winter, spring and autumn, but decrease in summer by the maximum (minimum) 37.5 $\mathrm{m}^{3} / \mathrm{s}\left(14.3 \mathrm{~m}^{3} / \mathrm{s}\right)$ and maximum (minimum) $36.2 \mathrm{~m}^{3} / \mathrm{s}\left(14.3 \mathrm{~m}^{3} / \mathrm{s}\right)$ for the A2 scenario. The overall scenario shows a decreasing discharge in summer in Langtang Khola, which may be due to the decreasing glacier area, and as a result the glacier melt contribution is less.

\section{CONCLUSION}

Performance of SDSM downscaling based on NCEP and GCMs predictors at Langtang, Kyanging are evaluated using statistical properties of daily climate data. It was found that the application of SDSM for statistical downscaling is suitable for developing daily climate scenarios. To demonstrate the procedure of developing scenarios, SDSM is applied, based on daily outputs of common climate variables from GCMs simulation, which has been widely used in the development of daily climate scenarios, and the results can be used in many areas of climate change impact studies. According to this study, the autumn temperature is much warmer compared to winter, spring and summer. The precipitation is increased for NCEP calibrated scenarios for spring, summer and autumn, whereas in winter it is decreased. The model generally projected an increase of precipitation during summer and spring, and a decrease during winter and autumn seasons. However, maximum projected discharge will increase for all seasons except for spring compared to a minimum projected discharge in summer.

Acknowledgments The author(s) would like to acknowledge the Data Access Integration (DAI, see http://quebec.ccsn.ca/DAI/) Team for providing the data and technical support. The DAI data download gateway is made possible through collaboration among the Global Environmental and Climate Change Centre (GEC3), the Adaptation and Impacts Research Division (AIRD) of Environment Canada, and the Drought Research Initiative (DRI). The Ouranos Consortium (in Québec) also provides IT support to the DAI team. We show appreciation to the Department of Hydrology and Meteorology (DHM), Government of Nepal for providing necessary data for this study.

\section{REFERENCES}

Immerzeel, W. W. et al. (2011) Hydrological response to climate change in a glacierized catchment in the Himalayas. Climatic Change DOI 10.1007/s10584-011-0143-4.

Reddy P. Jaya Rami (2005) A Text Book of Hydrology. Laxmi Publications 7/21, Ansari road, Daryaganj, New Delhi 110002.

Seibert, J. (2005) HBV light version 2, User's Manual, Uppsala University, Institute of Earth Sciences, Department of Hydrology, Uppsala, Sweden.

Wilby, R. L. and Dawson, C. W. (2007) Statistical Downscaling Model (SDSM) Version 4.2 user manual. 